Bond University

Research Repository

\title{
Resources supporting entrepreneurial orientation in multigenerational family firms
}

Irava, Wayne; Moores, Ken

Published in:

International Journal of Entrepreneurial Venturing

DOI:

10.1504/IJEV.2010.03711

Licence:

Unspecified

Link to output in Bond University research repository.

Recommended citation(APA):

Irava, W., \& Moores, K. (2010). Resources supporting entrepreneurial orientation in multigenerational family firms. International Journal of Entrepreneurial Venturing, 2(3/4), 222-245.

https://doi.org/10.1504/IJEV.2010.03711

\section{General rights}

Copyright and moral rights for the publications made accessible in the public portal are retained by the authors and/or other copyright owners and it is a condition of accessing publications that users recognise and abide by the legal requirements associated with these rights.

For more information, or if you believe that this document breaches copyright, please contact the Bond University research repository coordinator. 


\title{
Resources supporting entrepreneurial orientation in multigenerational family firms
}

\author{
Wayne Irava* \\ Fiji School of Medicine, Fiji \\ E-mail: w.irava@fsm.ac.fj \\ *Corresponding author \\ Ken Moores** \\ Australian Centre for Family Business, \\ Bond University, Gold Coast, Queensland 4229, \\ Australia \\ E-mail: kmoores@bond.edu.au
}

\begin{abstract}
We examine entrepreneurship in multigenerational family firms. Specifically, we employ theoretical lenses drawn from both entrepreneurship (entrepreneurial orientation) and strategy (resource-based view) to develop an integrated model of transgenerational entrepreneurship. Following a review of the literature in these fields we develop propositions that articulate connections between a family firm's unique bundle of resources (familiness), its entrepreneurial orientation (EO), and the achievement of its non-financial performance objectives (NFPO). In this way the paper not only contributes to the debate concerning the link between family background and entrepreneurial behaviour but also helps clarify the broad construct familiness in terms of the nature of resources within the unique bundle.
\end{abstract}

Key words: Resource-based view, Entrepreneurial Orientation, Transgenerational Entrepreneurship, Non-financial performance objectives

\section{Bibliographical notes:}

*Wayne Irava was a doctoral candidate at the Australian Centre for Family Business (ACFB), Bond University.

**Dr. Moores is Professor and Founding Director, Australian Centre for Family Business (ACFB), School of Business Bond University 


\section{Introduction}

Resource-based theory (Barney 1991; Penrose 1959; Wernerfelt 1984) and the entrepreneurship field (Gartner 1990; Schumpeter 1934; Stevenson and Jarrillo-Mossi 1986) have gained considerable momentum in their development and have generated much interest and momentum over recent years in strategic management. While resource-based theory and the entrepreneurship field have primarily evolved separately in the literature, nonetheless they are closely related. Alvarez and Busenitz (2001) suggest that the next generation of research on resource-based theory and entrepreneurship should be more closely connected. They suggest that bridging the gap between these fields requires an understanding of the lens through which they (resource-based theory and the entrepreneurship field) view resources. Resource-based theory has mainly focused on heterogeneity of resources while entrepreneurship has tended to focus on heterogeneity in beliefs about the value of resources (Alvarez and Busenitz 2001 p.756). Because heterogeneity of beliefs itself can develop into a strong resource, this alone suggests that greater synthesis between resource-based theory and entrepreneurship could be productive. Entrepreneurship then, in that light, can be seen as an inherently subjective and firm-specific resource. This paper bridges the gap between resource-based theory and the entrepreneurship field, by exploring them in the context of a unique set of firms: the family business.

The family firm is arguably the most enduring institution for entrepreneurial activity in emergent economies (Pistrui et al. 1997) and the ability to engage in entrepreneurial behaviour will depend, in part, on the firm's resources and capabilities (Covin and Slevin 1991). This paper posits that in multigenerational family firms it is familiness resources (Habbershon and Williams 1999; Habbershon et al. 2003), which are both idiosyncratic and a source of competitive advantage that can serve as either a catalyst for, or a restraint on, the form of entrepreneurship the family firm seeks to pursue.

To investigate the role of 'familiness' resources in nurturing and perpetuating entrepreneurialism in multigenerational family firms, we draw upon resource-based view (hereafter RBV) (Barney 1991; Wernerfelt 1984) and the entrepreneurial orientation (hereafter EO) concept (Lumpkin and Dess 1996; Miller 1983) from the entrepreneurship field as theoretical underpinnings, and examine their effect and interaction in the context of family firms. Specifically this paper addresses the question of how multigenerational family firms can develop the resources and capabilities required to survive across generations. We propose that 
the answer reside within the family and the resources generated because of the family's involvement in the business. Examining the role of family resources (familiness) in perpetuating entrepreneurial activity in the family business via the development of an EO in this way is consistent with the emerging perspective in the family business literature referred to as 'transgenerational entrepreneurship' (Cruz et al. 2006; Habbershon and Pistrui 2002; Habbershon et al. 2003). The paper presumes that the intangible "familiness" of a firm as explicated by RBV lends itself to actualization of an effective EO, and subsequently, the successful achievement of the firm's non-financial objectives.

Familiness resources will differ (Habbershon and Pistrui 2002; Habbershon and Williams 1999) and those firms that are able to harness and manage the distinctiveness of their familiness resources will have a greater propensity to sustain an EO and engage in entrepreneurial activity. Surviving across generations requires the firm to maintain an entrepreneurial mindset within every generation (Sirmon and Hitt 2003) thus recognising the family resources and practices that perpetuate an entrepreneurial mindset across generations is paramount. We further that understanding by exploring how the family resource steers entrepreneurial activity to sustain successful performance across generations of the family. We seek to highlight family resources and practices that help implement changes and support entrepreneurial activity and growth across generations of the family. These are the central arguments which this paper proposes and sets out to explore. The motivation is thus to clearly identify the entrepreneurial potential of the family in the family business as well as answer calls for greater integration between entrepreneurship and the family business fields. This research is beneficial to family firms that are committed to continuity and desire to remain entrepreneurial across generations.

The paper is structured as follows: we first begin by discussing the theoretical lens on which our paper is based. Second, we discuss familiness, EO, and non-financial performance (NFP) in the context of the family business and conclude with a series of propositions. Thirdly we present a conceptual model that diagrammatically presents our arguments and propositions. Finally we conclude the paper with a brief summary.

\section{Theoretical Foundations}

In this section we discuss the theoretical lenses that are central to the arguments presented in the paper. The lenses are the resource-base view 
(RBV) and entrepreneurial orientation (EO). Evidence of the nature of these resources, capabilities, and orientation in the context of family firms are then presented leading to the specification of propositions that collectively integrate these perspectives.

\section{Resource based view of the firm}

RBV has emerged as an influential internal resource perspective that has heightened the importance of a firm's internal resources (their nature, characteristics and potential) and their use in unique ways to create competitive advantage. The key assumption of RBV is that internal resources and capabilities of firms are heterogeneous in nature, thereby distinguishing among firms and presenting a competitive advantage (Barney 1991) that can provide sustained returns (Peteraf 1993). Thus the objective of RBV is to understand how firms can attain and sustain their competitive advantage via resource heterogeneity (Barney 1991; Penrose 1959; Wernerfelt 1984). This objective has been addressed by several scholars, who show that RBV is useful in examining strategic alliances between firms (Das and Teng 2000), in understanding the growth of firms (Penrose 1959; Pettus 2001), in determining technological innovation in small firms (Athanasios 2000), in addressing issues in entrepreneurship (Alvarez and Busenitz 2001), and in understanding failures in firms (Thornhill and Amit 2003), to name a few. Penrose's (1959) seminal paper in which the firm is considered as a set of entrepreneurial and managerial resources is one of the earliest contributions to RBV. Penrose emphasised that the "services that resources render are inputs in the productive process" (1959 p.24) and that "different services from similar resources make firms both heterogeneous and unique" (1959 p.75). Since Penrose, other notable contributions have been made to the refinement and conceptual clarity of the RBV (e.g. Barney 1991; Mahoney and Pandian 1992; Miller and Shamsie 1996; Peteraf 1993; Priem and Butler 2001; Wernerfelt 1984).

An area of interest around RBV originates from the dilemma of defining what a resource is, what makes resources unique, and how resources contribute to the competitive advantage of firms. Wernerfelt (1984 p.172) defined resources as "anything which could be thought of as strength or weakness of a firm and at any given time can be defined as those assets (tangible and intangible) which are tied semi-permanently to the firm". Miller and Shamsie (1996) extended that definition further by distinguishing intangible and tangible resources. They labeled intangible resources as those that were knowledge-based while the tangible resources were property-based. Intangible resources are more likely to result in 
sustained competitive advantage because they are often unknown and/or difficult to identify, and are firm-specific thus making them difficult and sometimes even impossible to replicate. Barney (1991) suggests valuable, rare, inimitable, and non-substitutable (hereafter VRIN) as the four indicators that ensures firm resources can provide a sustained competitive advantage.

RBV has deepened our understanding regarding how firm resources are applied and combined, what makes competitive advantage sustainable, the nature of rents, and the origins of heterogeneity (Peteraf 1993). In particular RBV has especially highlighted the intangible resources that influence a firm's competitive advantage; like the uniqueness and complexities of the intangible resources (i.e. familiness) in our firms of interest (the family business). This makes the application of RBV in a family context most appropriate.

\section{Entrepreneurship and Entrepreneurial Orientation}

Entrepreneurship is concerned with entrepreneurial activities such as the process by which people or organisations discover and exploit new business opportunities which exist within a market, revitalise existing businesses, or introduce new products or processes (Schumpeter 1934; Shane and Venkataraman 2000; Stevenson et al. 1989). The current trend in the entrepreneurship literature is to focus on analysing entrepreneurship from a firm level perspective and this paper follows suit because the emphasis here is on the entrepreneurial processes of the multigenerational family firm and the recognition of entrepreneurship as an organizational (Covin and Slevin 1991) and multigenerational (Handler 1990) phenomenon. The firm level definition suggested by Miller (1983) is adopted. Miller defines entrepreneurship as a multidimensional concept encompassing the firm's actions relating to product-market and technological innovation, risk-taking, and pro-activeness. An entrepreneurial firm is one that "engages in product market innovation, undertakes somewhat risky ventures, and is the first to come up with proactive innovations, beating competitors to the punch” (Miller 1983 p.771). Although the terminology for entrepreneurship at the firm level is inconsistent (Sharma and Chrisman 1999), the literature tends to agree (regardless the terminology) that firm level entrepreneurship is related to greater firm performance (Covin and Slevin 1989; Lumpkin and Dess 2001; Wiklund and Shepherd 2005). Firm level entrepreneurship is more commonly referred to as the firm's entrepreneurial orientation (EO). 
EO is regarded as the sine qua non of firms that seek to succeed in today's volatile and extremely dynamic business environment (Wiklund and Shepherd 2003) and is a reflection of the firm's commitment, capability and aspiration to pursue entrepreneurial activity. The EO construct is derived from the early work of Miller and Friesen (1978), who initially identified eleven strategy making process dimensions. In a follow up study, Miller (1983) provided the first operationalization of the EO construct, which was measured by three dimensions: innovation, risktaking, and proactiveness. This work proved to be a seminal contribution and was to become the most widely used pedestal for more recent studies in understanding firm level entrepreneurship (e.g. Wiklund and Shepherd 2005; Zahra and Covin 1995). Lumpkin and Dess (1996) added two more dimensions to the EO construct: autonomy and competitive aggressiveness. However these latter two dimensions are less widely used than the original three dimensions (innovation, risk-taking and proactiveness) proposed by Miller (1983). The initial operationalization of the EO scale by Miller was further refined and developed by Covin and Slevin $(1986,1989)$ and is currently considered the most rigorous EO instrument by researchers (Rauch et al. 2004). The dimensions of EO and their suggested definitions are summarised in Table 1.

Table 1 Definitions of Entrepreneurial Marketing

\begin{tabular}{|c|c|c|}
\hline Dimension & Reference & Definition \\
\hline \multirow[t]{4}{*}{ Innovation } & Schumpeter (1934 p.87) & $\begin{array}{l}\text { New combinations (technical, } \\
\text { marketing, and organizational } \\
\text { aspects)..., he also defined innovation } \\
\text { as the setting up of a new production } \\
\text { function }\end{array}$ \\
\hline & $\begin{array}{l}\text { Lumpkin \& Dess (1996, } \\
\text { p.142) }\end{array}$ & $\begin{array}{l}\text { Tendency to engage in and support } \\
\text { new ideas, novelty, experimentation, } \\
\text { and creative processes that may result } \\
\text { in new products, services, or } \\
\text { technological processes }\end{array}$ \\
\hline & $\begin{array}{l}\text { Zahra \& Covin (1995, } \\
\text { p.45) }\end{array}$ & $\begin{array}{l}\text { Product innovation refers to the ability } \\
\text { of a company to create new products or } \\
\text { modify existing ones to meet the } \\
\text { demands of current or future markets }\end{array}$ \\
\hline & Knight (1997 p.214) & $\begin{array}{l}\text { Pursuit of creative or novel solutions to } \\
\text { challenges confronting the firm, } \\
\text { including the development or } \\
\text { enhancement of products and services, } \\
\text { as well as new administrative } \\
\text { techniques and technologies for }\end{array}$ \\
\hline
\end{tabular}




\begin{tabular}{|c|c|c|}
\hline & & performing organizational functions \\
\hline \multirow[t]{2}{*}{ Risk-taking } & $\begin{array}{l}\text { Lee and Peterson (2000 } \\
\text { p.406) }\end{array}$ & $\begin{array}{l}\text { Willingness to assume risk. Individuals } \\
\text { who are willing to accept the } \\
\text { uncertainty and riskiness associated } \\
\text { with being self employed as opposed to } \\
\text { settling for the refuge of jobs within } \\
\text { organizations }\end{array}$ \\
\hline & $\begin{array}{l}\text { Zahra and Garvis (2000 } \\
\text { p.471) }\end{array}$ & $\begin{array}{l}\text { Disposition to support innovative } \\
\text { projects (e.g., international ventures), } \\
\text { even when the payoff from these } \\
\text { activities is uncertain }\end{array}$ \\
\hline \multirow[t]{3}{*}{ Proactiveness } & $\begin{array}{l}\text { Antoncic and Hisrich } \\
\text { (2001, p.499) }\end{array}$ & $\begin{array}{l}\text { The extent to which organizations } \\
\text { attempt to lead rather than follow } \\
\text { competitors in such key business areas } \\
\text { as the introduction of new products or } \\
\text { services, operating technologies, and } \\
\text { administrative techniques (quoting } \\
\text { Covin and Slevin, 1986, p.631) }\end{array}$ \\
\hline & $\begin{array}{l}\text { Lumpkin \& Dess (1996, } \\
\text { p.146) }\end{array}$ & $\begin{array}{l}\text { Taking initiative by anticipating and } \\
\text { pursuing new opportunities and by } \\
\text { participating in emerging markets }\end{array}$ \\
\hline & Zahra (1995, p.45) & $\begin{array}{l}\text { Capacity to beat competitors in } \\
\text { introducing new products, services, or } \\
\text { technologies to the market }\end{array}$ \\
\hline \multirow[t]{2}{*}{ Autonomy } & $\begin{array}{l}\text { Lumpkin \& Dess (1996, } \\
\text { p.140) }\end{array}$ & $\begin{array}{l}\text { The independent action of an } \\
\text { individual or a team in bringing forth } \\
\text { an idea or a vision and carrying it } \\
\text { through to completion. In general, it } \\
\text { means the ability and will to be self- } \\
\text { directed in the pursuit of opportunities. } \\
\text { In an organizational context, it refers to } \\
\text { action taken free of stifling } \\
\text { organizational constraints }\end{array}$ \\
\hline & $\begin{array}{l}\text { Lee and Peterson (2000, } \\
\text { p.406) }\end{array}$ & $\begin{array}{l}\text { The independent spirit and freedom } \\
\text { necessary to create new ventures }\end{array}$ \\
\hline Aggressiveness & $\begin{array}{l}\text { Lumpkin \& Dess (1996, } \\
\text { p.139) }\end{array}$ & $\begin{array}{l}\text { Type of intensity and head-to-head } \\
\text { posturing that new entrants often need } \\
\text { to compete with existing rivals }\end{array}$ \\
\hline
\end{tabular}

Initially the dimensions of the EO construct was seen to be positively correlated to each other (Covin and Slevin 1989). This meant that if a firm scored high on one dimension (e.g. risk-taking) then it was also expected to score high on the other dimensions (e.g. proactiveness and innovativeness). This view however has been challenged. Lumpkin and Dess (2001) assert that the EO dimensions need not covary but could exist 
to characterise EO as a multi-dimensional construct. Depending on certain conditions (e.g. hostile or benign environments, or type of entrepreneurial opportunity pursued) a firm could place greater emphasis on a certain EO dimension and therefore be stronger on that dimension while lower on others. This multi-dimensional concept that EO dimensions tend to vary independently rather than covary, is proving to be promising (Kreiser et al. 2001). EO as a firm level phenomenon is a useful framework for research into entrepreneurial processes of the firm. Entrepreneurial performing firms engage in firm activities that are either risk taking, innovative, or proactive (Covin and Slevin 1991) and entrepreneurial activity is a common characteristic of many family firms (Zahra 2007). Zahra (2003) suggests that research in entrepreneurship can be enriched if the contextual situations of investigations are given greater consideration in terms of understanding their nature, dynamics, uniqueness and limitations.

\section{The context of the family business}

Having discussed the theoretical lenses we next look at how these lenses are applicable within the context of the family business. Family businesses' dominate the economic landscape of most countries today (Eddy 1996; Morck and Yeung 2004) and are found to both outperform and under-perform in relation to non-family businesses (Dyer 2006). And while their dominance is challenged on the grounds of what defines a family business (Westhead and Cowling 1998), it is conclusive that the majority of all business start-ups (and entrepreneurs) are founded and nurtured within the social structure of the family (Aldrich and Cliff 2003).

\section{RBV and Familiness}

$\mathrm{RBV}$, as a theoretical framework has been instrumental in developing a theory for family business (Chrisman et al. 2005a). RBV has been most useful in highlighting the complexities and uniqueness of the internal mechanisms that operate when the family and the business interact. This uniqueness is referred to as 'familiness' and refers to the idiosyncratic firm level bundle of resources and capabilities that are generated when the family and the business interact and co-exist in unison (Habbershon and Williams 1999) giving family firms their distinction. The notion of familiness has become widely accepted within family business research and its popularity is evidenced by its growing attention in family business research (eg. Chrisman et al. 2005b; Habbershon 2006b; Moores and Craig 2005; Nordqvist 2005; Pearson et al. 2008; Rutherford et al. 2008; Sharma 2008; Tokarczyk et al. 2007; Zellweger et al. 2008), however as 
yet we do not understand the conditions that give rise to familiness nor yet fully understand the sources and types of familiness (Chrisman et al. 2005b). Familiness remains a somewhat 'fuzzy' concept and much exploration is crucial to understanding this idiosyncratic resource said to be persistent in family firms (Moores 2009). Thus the concept of familiness is being continually refined and developed as a construct within family business research.

In general the literature does concur that familiness is a possible source of sustainable competitive advantage for family firms. The term possible suggests that familiness can be both advantageous and disadvantageous (behaves as a 'double edged sword') depending on different conditions and triggers. Examples of these triggers include the organizational life cycle and family life cycle (Habbershon 2006a). A condition that encourages an advantage in one family firm may in contrast discourage the same advantage in another, or even cause a disadvantage. Donnelley (1964), one of the earliest contributors to the family business field, noted that strengths in one company may be weakness in another and that the firm needs to understand their situations so they can work out their courses of action. The weaknesses and strengths in family firms can be attributed to the familiness advantage and disadvantage factors respectively (Habbershon et al. 2003). In their clarification of familiness, Habbershon et al., (2003) propose that familiness resources can either be positive ( $\mathrm{f}+$ ) and therefore advantageous, or negative (f-) thereby constricting optimal firm performance. Competitive advantage results when there is more $\mathrm{f}+$ than $\mathrm{f}$-. However the exact conditions that determine when and where the familiness resource is likely to adopt either an $\mathrm{f}+$ or $\mathrm{f}$ - stance remain uncharted. Family firms in pursuit of a competitive advantage need to understand and manage the conditions and contextual factors under which familiness resources present an $\mathrm{f}+$ advantage for the firm.

Maintaining an $\mathrm{f}+$ advantage pertains to how well the firm is able to manage its familiness resources. Thus while the presence of familiness resources are necessary, they are not sufficient for competitive advantage. Family firms must possess the capabilities required to effectively manage and exploit these unique resources to their advantage (Sirmon and Hitt 2003). The ability to configure and leverage resources to appropriate rents is both creative and entrepreneurial (Barney and Arikan 2001) and leveraging resources and capabilities requires the integration of entrepreneurial and strategic management perspectives (Amit and Zott 2001). Therefore the ability to exploit and leverage the familiness 
resources to the firm's advantage depends on the entrepreneurial disposition of the firm. Lyon, Lumpkin and Dess (2000) find that an entrepreneurial disposition is a necessary antecedent to entrepreneurial actions essential for survival and growth. Cognitive science literature finds that actions result from one's mental modes, and correspondingly these entrepreneurial actions are outcomes of an entrepreneurial mindset (McGrath and MacMillan 2000). To promote continuity and success, family firms need to develop an entrepreneurial mindset that allows them to identify and exploit opportunities in their environments (Sirmon and Hitt 2003). Furthermore, the leveraging strategy family firms choose to effectively manage their resources is related to the aspirations and values of the family (Chrisman et al. 2003) and family values represent an idiosyncratic familiness resource that can act as a motive for intrapreneurship in family firms (Poza 1988).

Firms are heterogeneous through the idiosyncratic, immobile, imitable, and intangible bundle of resources that can generate competitive advantage and superior performance (Barney 1991). Firm performance is therefore better explicated by differences in the firm's resources (Miller and Shamsie 1996; Wiklund and Shepherd 2005). The unique and idiosyncratic bundle of resources in family firms, that arise out of the family's involvement in the business, are referred to as 'familiness' and are said to differentiate family firms from non-family firms (Habbershon et al. 2003). Extant literature suggests that familiness resources enhance performance in family firms (Chrisman et al. 2005b; Lester and Cannella 2006; Nordqvist 2005; Tokarczyk et al. 2007; Zellweger et al. 2008). Conversely, familiness resources can be detrimental to the performance of the family firm (Dyer 1986; Leenders and Waarts 2003; Stewart 2003). Therefore familiness resources can affect performance in both positive and negative ways and this results from their distinctive $(\mathrm{f}+)$ and constrictive nature (f-) (Habbershon et al. 2003).

The conditions that influence the nature that a firm's familiness resource takes remain sketchy (Chrisman et al. 2005b). There have been attempts in the literature to address some of these conditions. For example, familiness may be a function of the structure or culture of the family unit (Kellermanns 2005; Sharma and Manikutty 2005). In mutigenerational family firms, such cultures have persisted over generations thus enabling a stronger development of their familiness resources and providing them greater uniqueness. Also how the essential features of a family business (ownership, management, and transgenerational sustainability) interact, influences their familiness resources (Chrisman et al. 2005b) which in turn affects firm performance. Moreover because familiness can be both 
positive and negative, the challenge is to recognize the conditions that give rise to their constrictive and distinctive nature. This can allow the family firm to capitalise on the advantages of the distinctive nature and simultaneously manage the adverse effects of their constrictive nature.

We refer to the distinctive and constrictive effect of familiness as comprising its paradoxical nature. Moores and Barrett (2002) mention this paradoxical nature when they studied the learning cycle in family firms. Nordqvist et al. (2008) also allude to this paradox although in their research they labelled these as the 'dualities' in family firms. Handy (1994) says that paradoxes are inevitable and cannot be resolved; the best one can do is manage them. The ability to manage the distinctive and constrictive natures of familiness resources exists within the capabilities of the firm. While the resource profile is important to firm performance, it must be integrated and deployed effectively to achieve competitive advantage (Hitt et al. 2001). Penrose's (1959) theory of the growth of the firm states that the ability of any firm to create and maintain a competitive advantage depends on how well that firm's resources are managed; specifically with reference to management capabilities. These capabilities, as Teece et al. (1997) articulates, are fundamentally dynamic as they enable the firm to respond effectively to changes in the internal and external environments in the effort of generating and maintaining its competitive advantage. Whether an organization gains a competitive advantage and thereby achieves above normal returns will be a function of the strategy used to leverage those resources (Sirmon and Hitt 2003). However the strategies used on the resources is determined by the aspirations and values of the family (Chrisman et al. 2003). Accordingly we propose,

\section{P1a: Familiness is most advantageous to the family firm when its paradoxical nature is understood and managed according to prevailing conditions}

\section{P1b: The ability to manage the familiness paradox is dependent on the capabilities of the firm.}

\section{Entrepreneurship and the family business}

Research on entrepreneurship and the family business, have recently, attracted most interest to date. This is because the family business field has not explicitly identified the entrepreneurial potential of the family 
ownership group nor adequately delineated the strategic requirements for families in wealth creation (Habbershon and Pistrui 2002). While empirical evidence suggests that families play an important role in the venture creation process (Timmons 2004), little attention is given to the family perspective in the entrepreneurship literature (Aldrich and Cliff 2003). The family's entrepreneurial contribution and its justification to the family firm remain largely absent although the family is a distinct unit of analysis capable of sustainable entrepreneurial behaviour over time (Cruz et al. 2006). Entrepreneurship in general has been under-researched in the family business context (Eddleston et al. 2008). Family business and entrepreneurship are two parallel streams of theory and practice that have lacked integration (Dyer and Handler 1994) and Hoy and Vesper (1994) suggest that whilst the two may be independent, they are overlapping fields. Aldrich and Cliff (2003) find little concern given to the family and a social embeddedness perspective in entrepreneurship literature. Researchers need to include family dimensions in their conceptualising and modelling since family businesses are made up of families who are the most compelling social institution (Gersick et al. 1997) and a more accurate picture of entrepreneurship emerges when it is viewed as a social rather than an individual activity (Byers et al. 1997). Moreover the family network system plays a dominant role in supporting entrepreneurship and enterprise development (Pistrui et al. 1997). Given that the family business is a hospitable environment for entrepreneurial activity (Rogoff and Heck 2003) their exploration is essential.

Selznick (1957 p.91) stresses that the purpose of an enterprise is birthed from the underlying social structure of the firm. Entrepreneurship draws from the social context which shapes and forms entrepreneurial outcomes (Jack and Anderson 2002). Social networks facilitate the activities of entrepreneurs and are essential to providing resources for new ventures (Aldrich and Zimmer 1986). In family firms this social context is the family and therefore family owned businesses are appropriate units of entrepreneurial analysis. The birthplace of entrepreneurial ventures is often in the home and the family is the most enduring institution for entrepreneurial activity (Pistrui et al. 1997). Exposure to family transitions heightens an individual's orientation towards entrepreneurial activities (Kellermanns and Eddleston 2006) and entrepreneurial activity is a common characteristic of many family firms (Zahra 2005; Zahra et al. 2004). Changes in family transitions and compositions have implications for the venture creation decision, emergence of new business opportunities, opportunity recognition, and resource mobilization (Aldrich and Cliff 2003). Kinship ties unique to family firms show a positive effect 
upon entrepreneurial opportunity recognition (Barney et al. 2003), and family involvement has a consistent impact on the perceptions and performance of new ventures (Chrisman et al. 2002).

Several studies (Aldrich and Cliff 2003; Heck et al. 2006; Zahra et al. 2004) have found the family to play an influential role in facilitating and nurturing entrepreneurship in family firms. Achieving and sustaining entrepreneurial behaviour across long periods of time is often a family's primary concern (Habbershon and Pistrui 2002). Salvato and Melin (2005) accentuate that the social interactions (trust, norms, obligations and expectations) among members of the controlling family is what makes a family firm more (or less) capable of long-term entrepreneurial adaptation. In family firms, the social interactions are heavily influenced and shaped by family values, beliefs, attitudes, and expectations of the owning family (Beckhard and Dyer Jr 1983; Hall et al. 2001; Peredo 2003). Hall, Melin, and Nordqvist (2001) found that explicit and open cultures in family firms encourage and foster entrepreneurial change. Zahra, Hayton, and Salvato (2004) found that cultural orientations play a more prominent role in entrepreneurial activities in family firm's vis-à-vis non-family firms. The culture in family firms can foster an entrepreneurial mindset that will help them to identify and exploit opportunities in their environments thus promoting continuity and success (Sirmon and Hitt 2003). The above discussion suggests that families contribute significantly to entrepreneurial activity and thus deserve greater attention in the entrepreneurship literature.

Studying entrepreneurship within the family business context requires a firm level approach of which the most widely used is the EO construct. While the EO construct has been studied in the entrepreneurship literature for over two decades, it is only recently that it has been explored in the context of the family business. Since then EO has quickly gained popularity within the family business field and has progressed the scholarship and discipline in research between entrepreneurship (via EO) and the family business field. However there is still need for greater exploration to further strengthen, substantiate, and enrich current theories.

One way of enriching theories is looking at the equivocality in family business research. Here the focus of the discussion concerns EO and family business. The question of whether family firms have a greater propensity towards an EO than other forms of businesses remains of interest to family business researchers. This question has been addressed mostly with risk-taking, the most popular of the EO dimensions. Some researchers find risk-taking to be characteristic of family firms: Aronoff 
and Ward (2001) find risk-taking as one of the values of successful family businesses; Zahra, Hayton, and Salvato (2004) find family firms because of their long-term nature have a propensity towards dedicating resources to innovation and risk-taking; and Gomez-Mejia and colleagues (2007) find that family firms take greater risks in order to retain family control and family wealth. In contrast other researchers have found family firms to lack a risk-taking propensity: Naldi et al. (2007) found that family firms take less risks compared to non-family firms and that risk taking in family firms is negatively related to performance; Carney (2005) finds family firms as risk averse and this keeps them from engaging in significant acquisitions; and McConaughy et al. (2001) find family-controlled firms use capital structures that have less risk. Some other studies (e.g. Lumpkin and Sloat 2001) find no significant differences between family firms and non-family firms concerning risk-taking. These above mentioned studies highlight the equivocality that exists but also suggests that this equivocality may be driven by the composition of family firms used in the study. The equivocality may also be driven by 'dualities' such as historical/new path duality, independence/dependence duality, and the formality/informality duality (Nordqvist et al. 2008).

Salvato (2004) was one of the first to investigate EO across the composition of family firms by examining the predictors of EO across three types of family firms: founder centred, cousin consortium, and open family firms. Salvato found the main predictors to be individual CEO characteristics, aspects of the relationship between family and firm, governance and organizational characteristics, and ownership structure. These predictors differed across the three family firm types and suggest that generational involvement of the family can influence entrepreneurial activities in family firms. Salvato concluded that different levers are needed to foster entrepreneurship, depending on the type of family firm under study. A later study by Kellermanns et al. (2008) supported Salvato's findings that generational involvement has a positive effect on entrepreneurial behavior. Contrary to Salvato (2004), Kellermans and Eddleston (2006) found that generational involvement did not directly affect corporate entrepreneurship (measured by EO). Instead their study found that willingness to change and perceived technological opportunities had a significant impact on corporate entrepreneurship. Generational involvement did show a significant effect but only when it was moderated by strategic planning. Their study suggests that unless family firms display some degree of strategic planning, resources alone (in their case multiple family generations) are insufficient for corporate entrepreneurship. Their study echoes Penrose (1959) who noted that productive opportunity 
resulted not just from resources, but also from the dynamics of entrepreneurial judgement at the level of the managerial team. Management of resources was necessary to drive entrepreneurial activity.

Martin and Lumpkin (2003) found in their study of 927 family firms that over the generations there is a tendency to favour a family orientation (FO) over an EO. A FO was dominant when concerns of the family business centred on issues of control, risk aversion, strategic conservatism, and protection of the family. They proposed that an FO that exists in opposition to an EO negatively affects firm performance. In their study, three dimensions of EO (autonomy, risk-taking, and competitive aggressiveness) decreased in successive generations as the levels of FO increased. These findings suggest that an FO can negatively influence the firm's EO. However Leenders and Waarts (2001) suggest that an FO does not always create barriers to a firm's EO stance and it is possible for generational family firms to possess a FO that supports an EO. More recently Nordqvist et al. (2008) in their in-depth qualitative study of two family firms found that across generations characteristics that support a sustained EO can emerge alongside a FO. Zahra (2005) studied the conditions under which family firms encouraged entrepreneurial activity and found that the higher the number of generations from the same owner family that are active in the company, the higher the focus on innovation. Contrary to Kellermans and Eddleston (2006), Zahra finds generational family involvement to have a positive effect on entrepreneurial activity within the firm; specifically innovation, one of the three dimensions of the EO concept. In contrast Athanasios (2000) finds that greater family involvement results in lower firm innovativeness in small firms. Again all these studies further highlight the equivocality in findings regarding EO and family business.

Understanding the effect of familiness resources on the family firm's EO is pivotal if family firms endeavour to remain entrepreneurial across generations. The "familiness" approach which has its roots in the RBV of the firm (Habbershon et al. 2003) can be used to examine the nature of the family's influence on the EO of the family business. The emphasis here is on familiness resources and how they are beneficial for EO and long-term performance advantage.

EO is a resource consuming strategy by serving to integrate and focus resources, potentially resulting in (or enhancing) a competitive advantage. Hence the pursuit of entrepreneurial strategies requires resources (Wiklund and Shepherd 2005) and resources play an essential role in the firm's ability to be entrepreneurial (Galunic and Eisenhardt 1994). 
Resources and competencies provide the basis for all forms of organizational action and as a result entrepreneurial activity is limited by a firm's resource base and affected by the type of resources possessed by the firm (Covin and Slevin 1991). In family firms the relationship between entrepreneurship and resources are both positive and linear (Zahra and Salvato 2002). The family's capability for long-term entrepreneurial adaptation lies in the social resources (specifically interactions) among members of the controlling family (Salvato and Melin 2005). Concentrated ownership in family firms can enhance the speed of communication and decision making which is vital in dynamic environments for first mover advantages (Carney 2005). Zahra et al., (2004 p.363) find that the long term nature of ownership in family firms allow them to "dedicate resources to innovation and risk taking, thereby fostering entrepreneurship". Schwass (2005) found the winning characteristics of family firms are an entrepreneurial drive, innovation, strong family leadership, and family values. Miller and Le Breton-Miller (2004) found two distinctive characteristics that were common to their sample of long lasting family firms. Firstly, these firms successfully sustain survival and viability across generations of the family. Secondly, each generation of owners added value to the business during their tenure.

We contend that in family firms, familiness resources strongly influence the firm's EO. This influence is heightened in multigenerational family firms who have had years of experience in managing the family's influence in the business. The majority of family firms that dominate the economic landscape (Eddy 1996; Morck and Yeung 2004) and outperform their non-family counterparts (Anderson and Reeb 2003; Dyer 2006; Miller and Le Breton-Miller 2005) are multigenerational. This is testament to their performance and entrepreneurial capability. Longevity and successful performance in these firms could conceivably be attributed to their EO. Multigenerational family firms having passed through various environmental changes and at least more than one organizational and/or family life cycle would have had the opportunity to master the process of continuously assessing its familiness influence. These firms permit a better understanding of the phenomenon of how family resources sustain and contribute to entrepreneurial practices within the family business, over generations.

Also the EO that the firm pursues will influence the familiness resources the firm requires, employs and reinforces. For instance, firms in turbulent environments will find it desirable to innovate and grow (Naman and Slevin 1993), while firms in environments of low munificence heighten the importance of managing resources (Sirmon et al. 2007). In 
these different environments, a different EO strategy is necessary and consequently different sets of resources will be required and reinforced. And because familiness resources can change orientation (i.e. $\mathrm{f}+$ or $\mathrm{f}-$ ) due to changes in organizational or firm life cycles (Habbershon 2006a), the family firm needs to continually evaluate and manage its familiness influence to ensure it remains distinctive for the firm and its engagement in entrepreneurial activity.

Familiness resources are thus a vital part of the entrepreneurial process. A key role of the family firm is to determine, access, and deploy the necessary and appropriate resources. While it was earlier proposed that resources affect entrepreneurial activity (and they certainly do), it is the capabilities of the firm that enables engagement in entrepreneurial behaviour, and in so doing influence the specific form of entrepreneurship in which the firm engages (Covin and Slevin 1991). Gaining access to a variety of resources and knowing how to leverage them creatively are core entrepreneurial functions (Sexton 1991, quoted in Ireland et al. 2001). Hence the effective management and utilisation of resources is as vital, as the resource itself (Sirmon and Hitt 2003), to the entrepreneurial process of the family firm. A firm may achieve rents not because it has better resources, but because the firm's distinctive competence enables the firm to make better use of its resources (Mahoney and Pandian 1992; Penrose 1959). In other words while a family firm may be high in familiness resources, it will not achieve maximal performance unless the firm possesses the capabilities to effectively utilise and manage those familiness resources to achieve its entrepreneurial outcomes. Competitive advantages are grounded in the resources and capabilities the firm uses to perform value-adding transactional activities (Porter 1985) and it is the interaction, balance, and management of resources and capabilities that will lead to competitive advantage.

The notion of firm capabilities is better understood using the 'dynamic capabilities approach'(Eisenhardt and Martin 2000; Teece et al. 1997). This approach, which originates from RBV, identifies the "dimensions of firm-specific capabilities that can be sources of advantage, and explains how combinations of competencies and resources can be developed, deployed and protected" (Teece et al. 1997 p.10). It places emphasis on the internal processes that a firm utilises, as well as how they are deployed and how they will evolve. In the context of family firms, the approach is appropriate because it emphasizes the development of management capabilities, and difficult-to-imitate combinations of organizational skills. The 'difficult-to-imitate' capabilities can be termed 'unique capabilities', 
which arise from family involvement, and may be separated from the notion of 'familiness resources'. This distinction is important because it is possible for firms to be endowed with resources, but lacking the capability to effectively maximise the full potential of those resources (Sirmon and Hitt 2003). On the other hand, possessing the necessary capabilities but without access to resources that are VRIN is inadequate for sustained competitive advantage. The firm's capabilities must be distinctive to achieve superior levels of success in competitive markets (Day 1994). Capabilities per se do not enhance the firms EO, but together with resources, they are essential for determining successful outcomes from the adopted EO. We postulate that multigenerational family firms possess both the familiness resources and capabilities that have allowed them to successfully remain entrepreneurial across generations. We propose,

\section{P2a Distinctive familiness resources in multigenerational family firms are positively associated with an Entrepreneurial Orientation (EO)}

\section{$P 2 b$ This association is influenced by the presence of the firm's capabilities.}

\section{EO and non-financial performance in the family business}

Previous literature highlights a strong relationship between EO and firm performance (Covin and Miles 1999; Lumpkin and Dess 1996; Wiklund and Shepherd 2005; Zahra 1991). A synthesis of results of prior research exploring that relationship shows a positive correlation (Rauch et al. 2004) suggesting that better firm performance is attainable via the adoption of a strategic EO. In addition the EO-firm performance relationship is found to be sustainable over time (Wiklund 1999) and is suggested as one that possibly 'cuts both-ways' (Lumpkin and Dess 1996; Rauch et al. 2004). This means that EO and firm performance have the capacity to effectively influence each other. When the firm adopts an EO that results in better performance (positive association), the improved performance will present the firm with greater incentive to further strengthen its commitment to that adopted EO. When this EO strategy ceases to have a positive effect on firm performance (performance has levelled off or is declining) the firm can choose to either strengthen its current EO or to change it altogether. However such changes are both costly and time consuming and therefore the association between a firm's EO and its performance must be clearly established (Wiklund 1999) prior to a decision to change. Choosing to strengthen the current EO often 
resides in the firm's belief that better performance can yet be attained with such a stance. The choice to change its EO means a firm will need to redirect the engagement of resources towards finding and implementing an alternative EO strategy. A firm becomes entrepreneurial when it engages in an EO that becomes effective for the benefit of the firm (Lumpkin and Dess 1996). The challenge then for firms is having the ability to discern when it is appropriate to strengthen and when to change its EO to improve the firm's performance, amidst internal and external considerations.

A firm's EO-firm performance relationship can be influenced by internal (e.g. firm performance) and external (e.g. environment) factors. Previous studies examining this relationship find that certain variables exist as moderators and/or controls of this EO-Firm performance relationship. Common control variables include firm size, firm age, industry type, and past performance (e.g. Zahra 1991; Zahra and Covin 1995). Covin and Slevin (1989) found that the nature of the environment determined a firm's EO. Firms in hostile environments tend to display a more strategic entrepreneurial posture (i.e. EO) while firms in benign environments are characterised by a conservative strategic posture. Similarly organizational factors (Antoncic and Hisrich 2001), grand strategy or strategic planning (Zahra 1996), governance and ownership (Lumpkin and Dess 1996), and resource scarcity (Wernerfelt 1984) have also been found to influence the EO-performance relationship.

In family firms, research concerning the EO-firm performance relationship is scarce and remains equivocal. Notwithstanding their numeric dominance and capacity to outperform other firms, uncertainty remains as to whether family firms have a greater propensity to display EO characteristics (in comparison to non-family firms) and how this is influenced by family involvement. Certainly the presence of this equivocality highlights the need for greater research of the EO-firm performance relationship in the family business context (Heck et al. 2008) and greater importance lies in the need to better understand the underlying reasons that drive this equivocality.

The equivocality of the EO-firm performance relationship can be attributed to a range of potential explanations. These include the variety of methodological approaches used (Handler 1989), and the environments within which the sample of firms were extracted (Covin and Slevin 1989). The vast array of family business definitions adopted in prior research is also a contributing factor. The family business context constitutes a complex diversity of businesses (Sharma and Nordqvist 2008) with varied characteristics in the pursuit of diverse goals. However most studies have 
treated family firms as a homogenous class of organizations rather than accounting for the diversity that exists within the family business context (Sharma et al. 1997). There is yet a consensus on how exactly this diversity should be categorised although some typologies have been suggested (see for example Dyer (2006) and Gersick (1997)) which can help make sense of the reasons for the equivocal findings (Dyer, 2006). Another possible explanation for the equivocality is that the EO dimensions can vary independently depending on the organizational context (Lumpkin and Dess 1996). The strength of the EO-Firm performance relationship depends on internal organizational characteristics (Wiklund and Shepherd 2005). In researching EO as a strategic element, the organizational (and environmental) context is of great importance (Zahra 1993). Entrepreneurship is a context-dependent social process (Ireland et al. 2001) and attention must be given to the organizational context in which entrepreneurship (or EO) is studied. Family firms present one such organizational context and the focus here is specifically on multigenerational family firms who are ideal candidates for researching how familiness nurtures an EO across family generations and subsequently influences firm performance.

Prior studies looking at the EO-firm performance association have largely focused on financial performance (both objective and subjective) such as sales growth, employment growth, and financial indicators in the form of ratios (Wiklund 1999). However performance cannot be assessed purely on financial terms; holistically, it requires the inclusion of nonfinancial performance indicators. Lumpkin and Dess (1996) recommend that factors such as overall satisfaction and non-financial goals of the owners need greater consideration when evaluating performance, especially among privately held firms. There are also calls for entrepreneurship to be explored on non-financial performance and growth criteria (Zahra 1991). Despite this, non-economic goals remain an under researched topic in the family business literature (Debicki et al. 2009). A possible reason for this is that non-financial indicators are more challenging to ascertain and vary widely across firms.

In the family business context, financial and non-financial performance indicators are equally essential. Family firms are likely to have important non-financial goals, such as maintaining family harmony (Astrachan and Shanker 1996), family pride (Donnelley 1964), and job creation for family members (Morris et al. 1997). Such goals can develop into constraints that incur costs which adversely affect firm performance. Often the family is unable to avoid these costs and is reluctant to pay (Chua et al. 2006). While non-financial indicators are not exclusive to 
family businesses, their distinctiveness resides in their objectives: addressing the needs of the family (e.g. family control, involvement, reputation, and satisfaction).

Naman and Slevin (1993) suggest that in family firms there needs to be a balance in addressing business and family objectives. This means the business must create value for the family and likewise the family must add value to the business. When an orientation towards business dominates to the extent that family needs and their involvement are largely ignored, the essence of what it means to be a family business ceases. However if greater emphasis is on the pursuit of non-financial goals, this can alter economic performance if the development and deployment of resources are compromised (Chrisman et al. 2003). This can lead to businesses where family concerns dominate the agenda and dictate business objectives and strategies. There is a loss of professionalism and the firm suffers economically, often at the expense of the family. For performance to be sustainable there must be a synergistic and symbiotic relationship between the objectives of the family and that of the business (Chua et al. 2003).

The challenge then is in sustaining a beneficial symbiotic relationship. Longevity and success depends on being able to balance 'business like' and 'family like' thinking (Leenders and Waarts 2003). This challenge is heightened when financial and non-financial goals in family firms become inter-related via interlace of the family and business. Disengaging one from the other is difficult since often successfully achieving the most important family goal is often positively related to performing more business management activities (Lee et al. 2006). Positive changes in the financial position of the business are manifest in positive changes in the financial position of the family (Haynes et al. 2007). Schwass (2005) finds that successful family firms respect both the egalitarian culture of the family on one side and the meritocratic culture of the business on the other. Thus any assessment of the performance of the family business must include an assessment of the condition of the family. Generating that symbiotic relationship by alignment of interest between the firm and the family encourages the exploration of innovative ideas that stimulate growth and improves performance (Zahra 2005). Accordingly we propose,

\section{P3a Satisfying non-financial performance objectives in multigenerational family firms is associated with an Entrepreneurial Orientation}


$P 3 b$ This association is related to a family firm's ability to balance and leverage the dynamics of the family and the business over generations.

\section{Conceptual Model}

Previously we have presented a summary of the literature on RBV and the entrepreneurship field (EO), as well as shown how each theoretical frame has contributed to research in the family business context. The primary objective of the previous sections is the development of a conceptual model highlighting the association between the concepts of familiness resources, EO, and non-financial performance. The discussion suggested that the equivocality in family business research concerning EO can be explained by the nature of familiness resources and that the pursuit of an EO is not at the expense of achieving the family firm's non-financial objectives. Propositions generated from that discussion and which were presented for future hypothesis development and theory testing is illustrated in Figure 1.

Figure 1 Conceptual Model of Familiness, EO, and Firm Performance

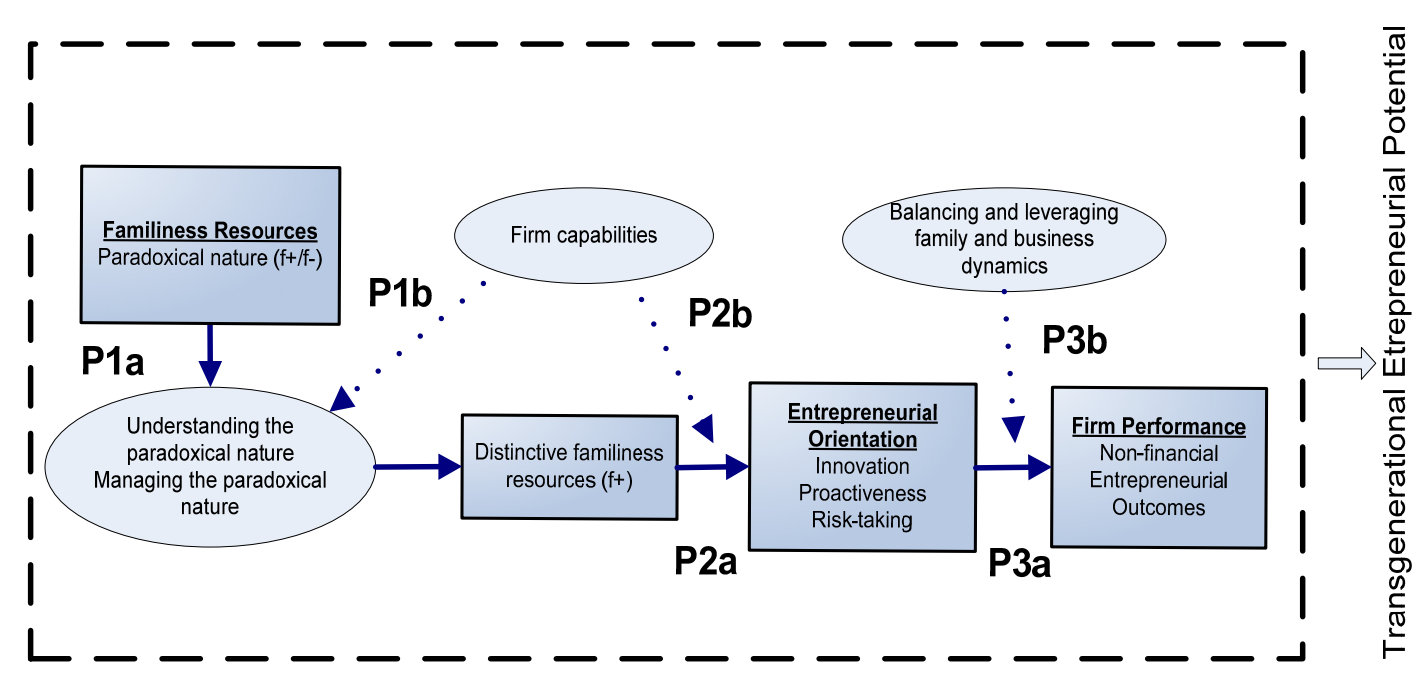

\section{Future research and implications}

This paper, being a conceptual contribution, requires empirical research to clarify and substantiate its propositions. The intangible nature 
of familiness, together with its as yet unexplored nature, suggests that as a start researchers may find it profitable to employ qualitative techniques such as case studies. The use of qualitative methods in family business research is relatively rare (Dyer and Marcelino 1998; Sharma 2004) although they have been noted as better suited to understanding multiple realities and addressing the tacit and micro-level aspects within the family firm (Goffee 1996). Furthermore, qualitative methods are suitable strategies where familiness as a construct is at an early formative stage, and prior knowledge on what variables exactly encompass familiness remains unclear.

The implications of such studies would not only clarify the resource dimensions (or bundle) that represent familiness but would help practitioners identify their familiness influence and thereby situate them in a better position to exploit their $\mathrm{f}+$ (familiness advantages) and mitigate their f- (familiness disadvantage). Furthermore, on identifying the familiness dimensions, research can then explore and determine which of these, when deployed within the family firm, influences a firm's EO.

\section{Conclusion}

We have argued that familiness resources present sustainable competitive advantages to family firms if the specific conditions are met. Firstly that familiness resources possess the characteristics of VRIN (Barney 1991), secondly that family firms understand the paradoxical nature of familiness and how familiness can simultaneously present both an advantage $(\mathrm{f}+)$ and disadvantage (f-) on the business, and thirdly that family firms have the capabilities to manage this paradoxical nature such that familiness provides $\mathrm{f}+$ outcomes that are greater than the $\mathrm{f}$ - outcomes. These conditions were integrated and presented in our conceptual model of how family firms can attain transgenerational entrepreneurial potential. Furthermore we have stated that the potential of family firms to maintain entrepreneurial capabilities across generations is associated with their familiness resources and that the pursuit of an entrepreneurial orientation can simultaneously assist family firms in achieving their non-financial objectives. These conditions were stated in propositions that provide fruitful avenues for future empirical testing. 


\section{References}

Aldrich, Howard E. and Jennifer E. Cliff. 2003. "The pervasive effects of family on entrepreneurship: toward a family embeddedness perspective." Journal of Business Venturing 18(5):573-596.

Aldrich, Howard E. and S Zimmer. 1986. Entrepreneurship through social networks. In The art and science of entrepreneurship, Eds. D.L. Sexton and R.W. Smilor: Ballinger, Cambridge, MA.

Alvarez, Sharon A. and Lowell W. Busenitz. 2001. "The entrepreneurship of resource-based theory." Journal of Management 27(6):755-775.

Amit, Raphael and Christoph Zott. 2001. "Value creation in E-business." Strategic Management Journal 22(6-7):493-520.

Anderson, Alistair R. and David M. Reeb. 2003. "Founding family ownership and firm performance: evidence from the S\&P 500." Journal of Finance 58(3):1301-1327.

Antoncic, Bostjan and Robert D. Hisrich. 2001. "Intrapreneurship: Construct refinement and cross-cultural validation." Journal of Business Venturing 16(5):495-527.

Aronoff, C.E. and John L. Ward. 2001. Family Business Values: How to Assure a Legacy of Continuity and Success: Family enterprise publishers.

Astrachan, Joseph H. and Melissa Carey Shanker. 1996. "Myths and Realities: Family Businesses' Contribution to the US Economy-A Framework for Assessing Family Business Statistics." Family Business Review 9(2):107-123.

Athanasios, Hadjimanolis. 2000. "A resource-based view of innovativeness in small firms." Technology Analysis \& Strategic Management 12(2):263-281.

Barney, Jay B. 1991. "Firm resources and sustained competitive advantage." Journal of Management 17(1):99-120.

Barney, Jay B. and A.M. Arikan. 2001. "The resource-based view: origins and implications." In Handbook of strategic management, eds. Michael A. Hitt, R.E. Freeman and J.R. Harrison. Oxford, UK.: Blackwell Publishers.

Barney, Jay B., D. Clark and S Alvarez. 2003. "Where does entrepreneurship come from? Network models of opportunity recognition and resource acquisition with application to the family firm." In Theories of the family enterprise conference. University of Pennsylvania, Philadelphia (December).

Beckhard, Richard and W. Gibb Dyer Jr. 1983. "Managing continuity in the family-owned business." Organizational Dynamics 12(1):4-12.

Byers, Tom, Heleen Kist and Robert I. Sutton. 1997. Characteristics of the entrepreneur: social creatures not social heroes. Boca Raton, Florida: CRC Press LLC.

Carney, Michael. 2005. "Corporate governance and competitive advantage in family-controlled firms." Entrepreneurship Theory and Practice 29(3):249265.

Chrisman, James J., Jess H. Chua and Pramodita Sharma. 2005a. "Trends and directions in the development of a strategic management theory of the family firm." Entrepreneurship Theory and Practice 29(5):555-575. 
Chrisman, James J., Jess H. Chua and Lloyd Steier. 2005b. "Sources and consequences of distinctive familiness: an introduction." Entrepreneurship Theory and Practice 29(3):237-247.

Chrisman, James J., Jess H. Chua and Lloyd P. Steier. 2002. "The influence of national culture and family involvement on entrepreneurial perceptions and performance at the state Level." Entrepreneurship Theory and Practice 26(4):113-130.

Chrisman, James J., Jess H. Chua and Shaker A. Zahra. 2003. "Creating wealth in family firms through managing resources: comments and extensions." Entrepreneurship Theory and Practice 27(4):359-365.

Chua, Jess H., James J. Chrisman and Lloyd P. Steier. 2003. "Extending the theoretical horizons of family business research." Entrepreneurship Theory and Practice 27(4):331-338.

Chua, Jess H., Lloyd P. Steier and James J. Chrisman. 2006. "How family firms solve intra-family agency problems using interlocking directorates: an extension." Entrepreneurship Theory and Practice 30(6):777-783.

Covin, Jeffrey G. and Morgan P. Miles. 1999. "Corporate entrepreneurship and the pursuit of competitive advantage." Entrepreneurship Theory and Practice 23(3):47-63.

Covin, Jeffrey G. and Dennis P. Slevin. 1986. "The development and testing of an organizational-level entrepreneurship scale." In Frontiers of Entrepreneurship Research, eds. R. Ronstadt, J.A. Hornaday, R. Peterson and K.H. Vesper: Wellesley, MA: Babson College.

Covin, Jeffrey G. and Dennis P. Slevin. 1989. "Strategic management of small firms in hostile and benign environments." Strategic Management Journal 10(1):75-87.

Covin, Jeffrey G. and Dennis P. Slevin. 1991. "A conceptual model of entrepreneurship as firm behavior." Entrepreneurship Theory and Practice 16(1):7-25.

Cruz, C, Timothy G Habbershon, Mattias Nordqvist, Carlo Salvato and Thomas Zellweger. 2006. "A conceptual model of transgenerational entrepreneurship in family influence firms." International Family Enterprise Research Academy - Jonkoping.

Das, T.K. and Bing-Sheng Teng. 2000. "A resource-based theory of strategic alliances." Journal of Management 26(1):31-61.

Day, George S. 1994. "The capabilities of market-driven organizations." Journal of Marketing 58(4):37.

Debicki, Bart J., Curtis F. Matherne, III, Franz W. Kellermanns and James J. Chrisman. 2009. "Family Business Research in the New Millennium: An Overview of the Who, the Where, the What, and the Why." Family Business Review 22(2):151-166.

Donnelley, Robert G. 1964. "The Family Business." Harvard Business Review 42(4):93-105. 
Dyer, W. Gibb. 2006. "Examining the "Family Effect" on Firm Performance." Family Business Review 19(4):253-273.

Dyer, W. Gibb Jr. 1986. Cultural change in family firms: anticipating and managing family business transitions. San Francisco: Jossey-Bass.

Dyer, W. Gibb Jr. and Wendy Handler. 1994. "Entrepreneurship and family business: exploring the connections." Entrepreneurship Theory and Practice 19(1):71-83.

Dyer, W. Gibb and Sachez Marcelino. 1998. "Current state of family business theory and practice as reflected in family business review 1988-1997." Family Business Review 11(4):287.

Eddleston, Kimberly A., Franz W. Kellermanns and Thomas Zellweger. 2008. "Corporate entrepreneurship in family firms: a stewardship perspective." In United States Association for Small Business and Entrepreneurship. San Antonio, Texas.

Eddy, Peg. 1996. "Lessons, legends and legacies: serving the family business." Journal of Financial Planning 9(6):76-79.

Eisenhardt, K.M. and Jeffrey A. Martin. 2000. "Dynamic capabilities: what are they?" Strategic Management Journal 21(10/11):1105-1121.

Galunic, D.C. and K.M. Eisenhardt. 1994. "Renewing the strategy-structureperformance paradigm." Research in Organizational Behavior 16:215-255.

Gartner, William B. 1990. "What are we talking about when we talk about entrepreneurship?" Journal of Business Venturing 5(1):15-28.

Gersick, Kelin E., John Davis, Marion Hampton and I Lansberg. 1997. Generation to generation: life cycles of the family business. Boston, Massachusetts.

Goffee, Rob. 1996. "Understanding family businesses: issues for further research." International Journal of Entrepreneurial Behaviour \& Research 2(1):36-48.

Gomez-Mejia, Luis R., Katalin T. Haynes, Manuel Nunez-Nickel, Kathyrn J. L. Jacobson and H. Moyano-Fuentes. 2007. "Socioemotional Wealth and Business Risks in Family-controlled Firms: Evidence from Spanish Olive Oil Mills." Administrative Science Quarterly 52(1):106-137.

Habbershon, Timothy G. 2006a. "Commentary: A Framework for Managing the Familiness and Agency Advantages in Family Firms." Entrepreneurship Theory and Practice 30(6):879-886.

Habbershon, Timothy G. 2006b. "The familiness impact on innovation in dominant smaller family firms: an exploratory investigation." Institute for family enterprising.

Habbershon, Timothy G. and Joseph Pistrui. 2002. "Enterprising families domain: family-influenced ownership groups in pursuit of transgenerational wealth." Family Business Review 15(3):223-237.

Habbershon, Timothy G. and Mary L Williams. 1999. "A resource-based framework for assessing the strategic advantages of family firms." Family Business Review 12(1):1-25. 
Habbershon, Timothy G., Mary L Williams and Ian C. MacMillan. 2003. "A unified systems perspective of family firm performance." Journal of Business Venturing 18(4):451-465.

Hall, Annika, Leif Melin and Mattias Nordqvist. 2001. "Entrepreneurship as a radical change in the family business: exploring the role of cultural patterns." Family Business Review 14(3):193-208.

Handler, Wendy C. 1989. "Methodological issues and considerations in studying family businesses." Family Business Review 2(3):257-276.

Handler, Wendy C. 1990. "Succession in family firms: a mutual role adjustment between entrepreneur and next-generation family members." Entrepreneurship Theory and Practice 15(1):37-51.

Handy, Charles. 1994. The age of paradox. Boston, Mass: Harvard Business School Press.

Haynes, George, Joseph Onochie and Glenn Muske. 2007. "Is What's Good for the Business, Good for the Family: A Financial Assessment." Journal of Family and Economic Issues 28(3):395-409.

Heck, Ramona K. Z., Sharon M. Danes, Margaret Fitzgerald, George Haynes, Cynthia Jasper, Holly Schrank, Kathryn Stafford and Mary Winter. 2006. "The family's dynamic role within family business entrepreneurship." In Handbook of research on family business, eds. Panikkos Poutziouris, Kosmas X. Smyrnios and Sabine Klein. Cornwall: Edward elgar publishing limited.

Heck, Ramona K. Z., Frank Hoy, Panikkos Z. Poutziouris and Lloyd P. Steier. 2008. "Emerging Paths of Family Entrepreneurship Research." Journal of Small Business Management 46(3):317-330.

Hitt, Michael A., R. Duane Ireland and Robert F. Hoskisson. 2001. Strategic management: competitiveness and globalization. Cincinnati, OH.: Southwestern College Publishing.

Hoy, Frank and Trudy G. Vesper. 1994. "Emerging Business, Emerging Field: Entrepreneurship and the Family Firm." Entrepreneurship Theory and Practice 19(1):9-23.

Ireland, R. Duane, Michael A. Hitt, S. Michael Camp and Donald L. Sexton. 2001. "Integrating entrepreneurship and strategic management actions to create firm wealth." Academy of Management Executive 15(1):49-63.

Jack, Sarah L. and Alistair R. Anderson. 2002. "The effects of embeddedness on the entrepreneurial process." Journal of Business Venturing 17(5):467-487.

Kellermanns, Franz W. 2005. "Family Firm Resource Management: Commentary and Extensions." Entrepreneurship Theory and Practice 29(3):313-319.

Kellermanns, Franz W. and Kimberly A. Eddleston. 2006. "Corporate Entrepreneurship in Family Firms: A Family Perspective." Entrepreneurship Theory and Practice 30(6):809-830.

Kellermanns, Franz W., Kimberly A. Eddleston, Tim Barnett and Allison Pearson. 2008. "An Exploratory Study of Family Member Characteristics and Involvement: Effects on Entrepreneurial Behavior in the Family Firm." Family Business Review 21(1):1-14. 
Knight, Gary A. 1997. "Cross-cultural reliability and validity of a scale to measure firm entrepreneurial orientation." Journal of Business Venturing 12(3):213-225.

Kreiser, Patrick, Louis Marino and K. Mark Weaver. 2001. "Assessing the psychometric properties of the entrepreneurial orientation construct: A multicountry analysis." In Presented at the 2001 Academy of Management Conference.

Lee, Sang M. and Suzanne I. Peterson. 2000. "Culture, Entrepreneurial Orientation, and Global Competitiveness." Journal of World Business 35(4):401.

Lee, Y. G., Sharon M. Danes and M. C. Shelley. 2006. "Work roles, management and perceived well-being for married women within family businesses." Journal of Family and Economic Issues 27(3):523-541.

Leenders, Mark and Eric Waarts. 2001. "Competitiveness of family business: distinguishing family orientation and business orientation." ERIM, Rotterdam School of Management, Erasmus Universiteit Rotterdam.

Leenders, Mark and Eric Waarts. 2003. "Competitiveness and Evolution of Family Businesses:: The Role of Family and Business Orientation." European Management Journal 21(6):686-697.

Lester, Richard H. and Albert A. Cannella. 2006. "Inter-organizational Familiness: How Family Firms Use Interlocking Directorates to Build Community-Level Social Capital." Entrepreneurship Theory and Practice 30(6):755-775.

Lumpkin, G. T. and Gregory G. Dess. 1996. "Clarifying the entrepreneurial orientation construct and linking it to performance." Academy Management Review 21(1):135-172.

Lumpkin, G. T. and Gregory G. Dess. 2001. "Linking two dimensions of entrepreneurial orientation to firm performance: The moderating role of environment and industry life cycle." Journal of Business Venturing 16(5):429-451.

Lumpkin, G. T. and Cheri B. Sloat. 2001. "Do family firms have an entrepreneurial orientation?", eds. William D. Bygrave, Erkko Autio, Candida G. Brush, Per Davidsson, Patricia G. Greene, Paul D. Reynolds and Harry J. Sapienza: Frontiers of Entrepreneurship Research.

Lyon, Douglas W., G. T. Lumpkin and Gregory G. Dess. 2000. "Enhancing entrepreneurial orientation research: operationalizing and measuring a key strategic decision making process." Journal of Management 26(5):1055-1085.

Mahoney, Joseph T. and J. Rajendran Pandian. 1992. "The resource-based view within the conversation of strategic management." Strategic Management Journal 13(5):363-380.

Martin, Wendy L and G.T. Lumpkin. 2003. "From entrepreneurial orientation to family orientation: generational differences in the management of family business." Frontiers of Entrepreneurship Research, Babson College. 
McConaughy, Daniel L., Charles H. Matthews and Anne S. Fialko. 2001. "Founding Family Controlled Firms: Performance, Risk, and Value." Journal of Small Business Management 39(1):31-49.

McGrath, Gunther Rita and Ian C. MacMillan. 2000. The entrepreneurial mindset: strategies for continuously creating opportunity in an age of uncertainty. Boston, Mass.; Great Britain: Harvard Business School Press.

Miller, Danny. 1983. "The correlates of entrepreneurship in three types of firms." Management Science 29(7):770-791.

Miller, Danny and Peter H. Friesen. 1978. "Archetypes of strategy formulation." Management Science 24(9):921-933.

Miller, Danny and Isabelle Le Breton-Miller. 2005. Managing for the long run: lessons in competitive advantage from great family businesses: Boston, Mass. : Harvard Business School Press.

Miller, Danny, Isabelle Le Breton-Miller and Lloyd P. Steier. 2004. "Toward an Integrative Model of Effective FOB Succession." Entrepreneurship Theory and Practice 28(4):305-328.

Miller, Danny and Jamal Shamsie. 1996. "The resource-based view of the firm in two environments: the hollywood film studios from 1936 to 1965." Academy of Management Journal 39(3):519-543.

Moores, Ken. 2009. "Paradigms and theory building in the domain of business families." Family Business Review 22(2):167-180.

Moores, Ken and Mary Barrett. 2002. Learning family business - paradoxes and pathways. Hampshire, England: Ashgate Publishing Company.

Moores, Ken and Justin Craig. 2005. "Balanced scorecards to drive the strategic planning of family firms." Family Business Review 18 (2):105-122.

Morck, Randall and Bernard Yeung. 2004. "Family control and the rent-seeking society." Entrepreneurship Theory and Practice 28(4):391-409.

Morris, Michael H., Roy O. Williams, Jeffrey A. Allen and Ramon A. Avila. 1997. "Correlates of success in family business transitions." Journal of Business Venturing 12(5):385-401.

Naldi, Lucia, Mattias Nordqvist, Karin Sjoberg and Johan Wiklund. 2007. "Entrepreneurial orientation, risk taking, and performance in family firms." Family Business Review 20(1):33-47.

Naman, John L. and Dennis P. Slevin. 1993. "Entrepreneurship and the concept of fit: A model and empirical tests." Strategic Management Journal 14(2):137153.

Nordqvist, Mattias. 2005. "Familiness in Top Management Teams: Commentary on Ensley and Pearson's 'An Exploratory Comparison of the Behavioral Dynamics of Top Management Teams in Family and Non-family New Ventures: Cohesion, Conflict, Potency, and Consensus'." Entrepreneurship Theory and Practice 29(3):285-291.

Nordqvist, Mattias, Timothy G Habbershon and Leif Melin. 2008. "Transgenerational entrepreneurship: exploring EO in family firms." In 
Current trends in entrepreneurship research (tentative title), ed. Landström $\mathrm{H}$. et al (forthcoming). Cheltenham: Edward Elgar.

Pearson, Allison W., Jon C. Carr and John C. Shaw. 2008. "Toward a Theory of Familiness: A Social Capital Perspective." Entrepreneurship: Theory \& Practice 32(6):949-969.

Penrose, Edith Tilton. 1959. The theory of the growth of the firm. 3rd Edition: Oxford University Press, New York:1995.

Peredo, Ana Maria. 2003. "Nothing Thicker than Blood? Commentary on "Help One Another, Use One Another: Toward an Anthropology of Family Business"." Entrepreneurship Theory and Practice 27(4):397-400.

Peteraf, Margaret A. 1993. "The cornerstones of competitive advantage: a resource-based view." Strategic Management Journal 14(3):179-191.

Pettus, Michael L. 2001. "The resource-based view as a developmental growth process: evidence from the deregulated trucking industry." Academy of Management Journal 44(4):878-896.

Pistrui, D., Harold P. Welsch and J. Roberts. 1997. "The [re]-emergence of family businesses in the transforming Soviet Bloc: Family contributions to entrepreneurship development in Romania." Family Business Review 10(3):221-238.

Porter, M.E. 1985. Competitive advantage. New York: The Free Press.

Poza, Erneston J. 1988. "Managerial practises that support interpreneurship and continued growth." Family Business Review 1(4):339-359.

Priem, Richard L. and John E. Butler. 2001. "Is the resource-based 'view" a useful perspective for strategic management research?" Academy Management Review 26(1):22-40.

Rauch, A., Johan Wiklund, M. Frese and G. T. Lumpkin. 2004. "Entrepreneurial orientation and business performance: cumulative empirical evidence." In 23rd Babson College Entrepreneurship Research Conference. Glasgow, UK.

Rogoff, Edward G. and Ramona K. Z. Heck. 2003. "Evolving research in entrepreneurship and family business: recognizing family as the oxygen that feeds the fire of entrepreneurship." Journal of Business Venturing 18(5):559566.

Rutherford, Matthew W., Donald F. Kuratko and Daniel T. Holt. 2008. "Examining the Link Between familiness and performance: can the F-PEC untangle the family business theory jungle?" Entrepreneurship: Theory \& Practice 32(6):1089-1109.

Salvato, Carlo. 2004. "Predictors of Entrepreneurship in Family Firms." Journal of Private Equity 7(3):68-76.

Salvato, Carlo and Leif Melin. 2005. "Transgenerational entrepreneurship in family firms: a dynamic capabilities approach." In Frontiers of Entrepreneurship Research 2005, ed. Zahra; Per Davidsson; Wiklund Johan; Greene Patricia; Shepherd Dean Shaker: Babson College.

Schumpeter, J. A. 1934. The theory of economic development. New Brunswick NJ: Transaction Publishers. 
Schwass, Joachim. 2005. Wise growth strategies in leading family businesses: Basingstoke [England] ; New York : Palgrave Macmillan.

Selznick, P. 1957. Leadership in administration: Berkeley, CA: University of California Press.

Shane, Scott and S. Venkataraman. 2000. "The promise of entrepreneurship as a field of research." Academy Management Review 25(1):217-226.

Sharma, Pramodita. 2004. "An overview of the field of family business studies: current status and directions for the future." Family Business Review 17(1):136.

Sharma, Pramodita. 2008. "Commentary: Familiness: Capital Stocks and Flows Between Family and Business." In Entrepreneurship: Theory \& Practice. 32 Edition.

Sharma, Pramodita and James J. Chrisman. 1999. "Toward a Reconciliation of the Definitional Issues in the Field of Corporate Entrepreneurship." Entrepreneurship Theory and Practice 23(3):11-27.

Sharma, Pramodita, James J. Chrisman and Jess H. Chua. 1997. "Strategic management of the family business: past research and future challenges." Family Business Review 10(1):1-36.

Sharma, Pramodita and S. Manikutty. 2005. "Strategic Divestments in Family Firms: Role of Family Structure and Community Culture." Entrepreneurship Theory and Practice 29(3):293-311.

Sharma, Pramodita and Mattias Nordqvist. 2008. "A classification scheme for family firms: From family values to effective governance to firm performance." In Family values and value creation: How do family-owned businesses foster enduring values, eds. J. Tapies and J.L. Ward: Palgrave Macmillan Publishers.

Sirmon, David G. and Michael A. Hitt. 2003. "Managing Resources: Linking Unique Resources, Management, and Wealth Creation in Family Firms." Entrepreneurship Theory and Practice 27(4):339-358.

Sirmon, David G., Michael A. Hitt and R. Duane Ireland. 2007. "Managing firm resources in dynamic environments to create value: looking inside the black box." Academy Management Review 32(1):273-292.

Stevenson, Howard H. and Jose Carlos Jarrillo-Mossi. 1986. "Preserving entrepreneurship as companies grow." Journal of Business Strategy 7(1):1023.

Stevenson, Howard H., Mark J. Roberts and H.I. Grousbeck. 1989. New business ventures and the entrepreneur. Irwin, IIlomewood, IL.

Stewart, Alex. 2003. "Help One Another, Use One Another: Toward an Anthropology of Family Business." Entrepreneurship Theory and Practice 27(4):383-396.

Teece, David J., Gary Pisano and Amy Shuen. 1997. "Dynamic Capabilities and Strategic Management." Strategic Management Journal 18(7):509-533.

Thornhill, Stewart and Raphael Amit. 2003. "Learning about failure: bankruptcy, firm age, and the resource-based View." Organization Science 14(5):497-509. 
Timmons, J.A. 2004. New venture creation: entrepreneurship for the 21st century. Boston: McGraw Hill.

Tokarczyk, John, Eric Hansen, Mark Green and Jon Down. 2007. "A resourcebased view and market orientation theory examination of the role of "familiness" in family business success." Family Business Review 20(1):1731.

Wernerfelt, B. 1984. "A resource-based view of the firm." Strategic Management Journal 5:171-180.

Westhead, Paul and Marc Cowling. 1998. "Family firm research: the need for a methodological rethink." Entrepreneurship Theory and Practice Fall:31-56.

Wiklund, Johan. 1999. "The sustainability of the entrepreneurial orientation-performance relationship." Entrepreneurship Theory and Practice 24(1):37-48.

Wiklund, Johan and Dean Shepherd. 2003. "Knowledge-based resources, entrepreneurial orientation, and the performance of small and medium-sized businesses." Strategic Management Journal 24(13):1307-1314.

Wiklund, Johan and Dean Shepherd. 2005. "Entrepreneurial orientation and small business performance: a configurational approach." Journal of Business Venturing 20(1):71-91.

Zahra, Shaker A. 1991. "Predictors and financial outcomes of corporate entrepreneurship: An exploratory study." Journal of Business Venturing 6(4):259-285.

Zahra, Shaker A. 1993. "Environment, corporate entrepreneurship, and financial performance: A taxonomic approach." Journal of Business Venturing 8(4):319-340.

Zahra, Shaker A. 1996. "Governance, ownership, and corporate entrepreneurship: The moderating impact of industry." Academy of Management Journal 39(6):1713-1735.

Zahra, Shaker A. 2005. "Entrepreneurial risk taking in family firms." Family Business Review 18(1):23-40.

Zahra, Shaker A. 2007. "Contextualizing theory building in entrepreneurship research." Journal of Business Venturing 22(3):443-452.

Zahra, Shaker A. and Jeffrey G. Covin. 1995. "Contextual influences on the corporate entrepreneurship-performance relationship: A longitudinal analysis." Journal of Business Venturing 10(1):43-58.

Zahra, Shaker A. and Dennis M. Garvis. 2000. "International corporate entrepreneurship and firm performance: The moderating effect of international environmental hostility." Journal of Business Venturing 15(56):469-492.

Zahra, Shaker A., James C. Hayton and Carlo Salvato. 2004. "Entrepreneurship in family vs. non-family firms: a resource-based analysis of the effect of organizational culture." Entrepreneurship Theory and Practice 28(4):363-381.

Zahra, Shaker A. and Carlo Salvato. 2002. "Organizational culture and entrepreneurship in family firms: a resource-based analysis." In Paper presented at 2nd Annual Conference on Theories of the Family Enterprise. Philadelphia, December. 
Zellweger, Thomas, Lucia Naldi and Mattias Nordqvist. 2008. "Intangible resources and performance in family firms: the moderating role of familiness." University of St.Gallen. 